\title{
KOMPOSISI TANAH UNTUK TEKNIK REPRODUKSI KERAMIK DI SENTRA GERABAH PAGERJURANG KLATEN
}

\author{
Arif Suharson \\ Dwita Anja Asmara *)
}

\begin{abstract}
The study aims to identify ideal formula of clay composition as the main material of functional ceramics produced in cylindrical and non-cylindrical shapes with the hand and feet rotating techniques. The rotating technique has some limitations because it cannot be employed in the making of non-cylindrical shapes. Even worse that the existing rotating techniques have failed to produce high-quality ceramics as demanded by consumers. Preciseness of size, shapes, and thickness of ceramic wall is a great concern and thus it is necessary to have the analysis of technical aspects and raw materials.

The ceramic products from Pagerjurang have attracted many foreign consumers. The products have to meet the specified standard of quality including the material, model/shape, size, and timeliness of order accomplishment. Reproduction technique is the appropriate solution to have the desired shapes, sizes, and thickness of ceramic wall. Manual experiments are required to test the quality of clay while laboratory testing is needed to test the chemical elements.

The ideal formula of clay composition as the main material of ceramic products in Pagerjurang will enable ceramic reproduction through single casting, multiple casting, and slip casting so that the expected export quality standard can be met. In this way, the preciseness of shape, size, and thickness of ceramic wall as well as diversified non-cylindrical products requested by consumers can be ensured. Thus it will provide better economic advantages for the ceramic artisans in Pagerjurang.
\end{abstract}

Key words: ceramic of pagerjurang, reproduction technique

\section{PENDAHULUAN}

Sentra gerabah Pagerjurang terkenal dengan sebutan keramik Bayat. Menurut cerita yang menjadi legenda masyarakat, keramik sudah ada sejak jaman Sunan Pandanaran. Yaitu seorang yang berguru pada Sunan Kalijaga sehingga mendapat julukan Sunan Pandanaran yang dimakamkan di daerah Bayat. Sehingga keramik disini terkenal dengan sebutan keramik Bayat. Keramik Bayat juga terkenal dengan teknik putar miringnya, dimana proses pembuatan produk-produk gerabah dibentuk dengan alat putaran yang

posisinya miring. Menurut Prof. Chitaru Kawasaki dari University Seika of Japan mengatakan bahwa teknik putar ini satusatunya di dunia dan menjadi kebanggaan masyarakat Pagerjurang. Produk-produk yang dibuat berupa pot, celengan, guciguci, vase bunga, teko set, kendi, dan produk-produk keramik silindris lainnya.

Bahan baku untuk membuat produk keramik diambil dari pegunungan Jabalakat yang terletak di daerah Bayat. Tanah liat yang digunakan untuk membuat gerabah sebenarnya sudah baik. Tanah tersebut memiliki tingkat keplastisan yang

\footnotetext{
*) Arif Suharson (arifkeramos@yahoo.com), Staf Pengajar Program studi Kriya Seni, Jurusan Kriya, Fakultas Seni Rupa, Institut Seni Indonesia Yogyakarta.

Dwita Anja Asmara (9putriarca@gmail.com), Staf Pengajar Program studi Kriya Seni, Jurusan Kriya, Fakultas Seni Rupa, Institut Seni Indonesia Yogyakarta.
} 
tinggi. Karena keplastisannya itu, sering tanah ini terlalu lengket dan susah dibentuk bila tidak dengan teknik putar. Ketersediaan bahan baku tanah dari gunung Jabalakat juga semakin menipis. Hal ini menjadi kekhawatiran perajin keramik di Pagerjurang untuk keberlangsungan proses produksinya. Sekarang ini gunung Jabalakat menjadi daerah Petilasan dan merupakan pegunungan dimana hutannya menjadi hutan yang dilindungi pemerintah. Dengan demikian terjadi larangan untuk mengambil tanah dalam jumlah yang besar.

Perkembangan keramik menuntut mutu produk keramik Pagerjurang semakin baik, yang didukung dengan bentuk-bentuk gerabah yang inovatif tidak terbatas pada bentuk-bentuk silindris saja. Menurut penuturan pengrajin, tanah liat dari Jabalakat memang cocok untuk teknik putar, tetapi tidak dapat digunakan untuk memproduksi gerabah non silidris terutama teknik cetak. Pengrajin juga pernah melakukan diversifikasi produk dengan cetak tetapi masih selalu lengket dan belum menghasilkan diversifikasi produk non silindris dengan baik. Karena keterbatasan inilah sebagian besar perajin enggan untuk melakukan inovasi bentuk dan pasrah dengan membuat keramik silindris dengan bahan tanah yang ada.

Keplastisan tanah dari gunung Jabalakat dan keterbatasan ketersediaannya menuntut untuk segera dilakukan pencarian tempat galian tanah yang baru. Sehingga proses produksi gerabah di Pagerjurang sebagai sumber penghasilan masyarakat tetap bisa berlangsung. Komposisi tanah yang ideal untuk melakukan teknik reproduksi harus dicari dan dilakukan percobaan-percobaan tanah sehingga akan ditemukan komposisi tanah ideal yang dapat dipergunakan sebagai bahan produksi gerabah. Validitas unsur kimia tanah yang terkandung di dalammnya harus diketahui, sehingga akan memberikan kemudahan dalam mengkomposisikan formula tanah yang seimbang dan dapat menjadi pedoman dalam mencampur tanah sebagai bahan baku yang lebih bermutu.

\section{HASIL PENELITIAN DAN PEMBAHASAN}

\section{Pendataan Tanah dan Pengambilan Sample Tanah}

Pendataan tanah telah dilakukan oleh peneliti di tempat penggalian bahan tanah liat/lempung yang sekarang masih dilakukan. Pendataan juga dilakukan disekitar daerah sentra untuk mencari alternatif pemikiran baru sebagai tempat penggalian tanah yang kemudian hari dapat dilakukan. Dari hasil test keramik di lapangan, tanah lempung yang dijadikan bahan baku sekarang tergolong plastis. Bahkan dari hasil pendataan di sekitar lokasi penggalian bahan baku tanah masih ada tempat galian lain yang masih memiliki kandungan yang sama di sekitar Gunung Merak, yang bersebelahan dengan Gunung Temugiring.

Keberadaan perbukitan yang saling menyambung dan struktur tanah yang sama dapat dipastikan juga memiliki kandungan lempung yang sama. Hal ini dipastikan dengan test keramik di lapangan yang telah dilakukan oleh tim peneliti. Bahan baku tanah lempung tersebut dapat diambil atau dapat menjadi galian tanah yang baru disekitar Gunung Santren, Gunung Temu Giring, dan Gunung Cakaran. Letaknya juga tidak begitu jauh dari Gunung Merak dan dapat dikatakan menjadi satu kawasan tanah lempung yang dapat dijadikan sebagai bahan baku utama pembuatan gerabah di sentra gerabah Pagerjurang. 


\section{Uji Tanah di Laboratorium Studio Keramik Jurusan Kriya FSR ISI Yogyakarta dan Laboratorium Fakultas Pertanian UGM Yogyakarta}

Pendataan tanah di lokasi penggalian tanah dan lokasi baru yang dapat dijadikan sebagai tempat penggalian tanah baru telah berhasil diidentifikasi. Untuk memastikan hasil tanah yang dapat digunakan atau diterapkan untuk teknik reproduksi keramik dengan media cetak perlu dilakukan kajian yang lebih lanjut. Pengkajian ini juga berguna untuk mengetahui unsur-unsur kimia dalam tanah secara pasti dan dapat digunakan sebagai pedoman untuk menyusun komposisi tanah yang ideal untuk produksi gerabah di sentra Pagerjurang. Sehingga hasil dan mutu tanah akan jauh lebih baik yang berdampak langsung pada hasil gerabah yang diproduksi oleh masyarakat Pagerjurang.

Tanah yang diambil di lokasi penggalian tanah kemudian diuji secara ilmu keramik di studio keramik Jurusan Kriya FSR ISI Yogyakarta. Pengujian tanah ini dimaksudkan untuk mengolah tanah dengan metode yang berbeda dimana tanah diolah dengan cara dipisah. Pemisahan dalam mengolah tanah akan memberikan dampak uji keplastisan tanah yang lebih terstruktur. Penimbangan dan pengukuran tanah juga dapat dilakukan dengan tepat. Sehingga akan diketahui tingkat keplastisan tanah yang ditunjukkan dalam tabel-tabel uji tanah.

Tidak hanya sampai pada pengolahan saja, akan tetapi tanah yang sudah diolah terpisah dilakukan pengujian lebih lanjut dengan membawa ke laboratorium tanah. Pengujian dilakukan di Fakukltas Geografi dan Pertanian UGM
Yogyakarta karena di studio keramik Jurusan Kriya ISI Yogyakarta belum memiliki laboratorium khusus kimia. Pengujian laboratorium sangat dibutuhkan untuk mengetahui unsur-unsur kimia dalam tanah sehingga akan memudahkan untuk menambah unsur-unsur lain. Penambahan unsur lain tersebut bertujuan agar tanah yang akan digunakan lebih memiliki plastisitas untuk teknik reproduksi sesuai capaian hasil penelitian yang diharapkan.

Setelah pengolahan tanah dilakukan yaitu dengan cara memisahkan ketiga jenis tanah tersebut, langkah selanjutnya baru mengolah tanah dengan mencampur ketiga jenis yang diuji dikomposisikan dengan ukuran-ukuran yang berbeda. Dari hasil komposisi tanah ini akan diuji dengan membuat lempenganlempengan terukur atau test-test pieces. Tanah hasil olahan juga diuji pada aplikasi tanah dengan membuat produk gerabah dengan teknik putar dan teknik reproduksi. Pengujian tanah yang dilakukan tidak hanya terbatas pada tanah yang digunakan oleh pengrajin Pagerjurang. Disini tanah dikombinasikan dengan bahan-bahan yang biasa digunakan dalam ilmu keramik, baik dengan bahan kimia atau mencampur dengan tanah dari daerah lain. Tanah yang diambil dari daerah lain merupakan tanah yang biasa digunakan untuk membuat gerabah seperti di daerah Kasongan, Pundong, dan Godean. Tanah dari daerah lain yang diambil masih berada di lokasi Yogyakarta. Sehingga bila hasilnya baik para pengrajin Pagerjurang masih dapat menjangkau untuk menggunakannya. 
Hasil test pieces tanah Pagerjurang di Studio Keramik Jurusan Kriya ISI Yogyakarta

\begin{tabular}{|c|c|c|c|}
\hline No & Kondisi Tanah & Ukuran $(\mathrm{cm})$ dan berat (gram) & Warna Tanah \\
\hline 1 & Basah & $\begin{array}{l}\text { Panjang basah } 10 \mathrm{~cm} \\
\text { Berat basah }=73,60 \text { gram }\end{array}$ & Coklat \\
\hline 2 & Kering & $\begin{array}{l}\text { Panjang kering } 9,4 \mathrm{~cm} \\
\text { Berat kering }=61,40 \text { gram }\end{array}$ & Coklat kekuningan \\
\hline 3 & Bakar/Bisquit & $\begin{array}{l}\text { Panjang bakar } 9,3 \mathrm{~cm} \\
\text { Berat bisquit kering } 56 \text { gram } \\
\text { Berat bisquit basah } 63,90 \text { gram }\end{array}$ & Merah bata \\
\hline
\end{tabular}

\section{Analisis:}

Bahan baku tanah berbentuk bongkahan kecil, tidak banyak mengandung air dan berpasir, dalam keadaan basah tanah ini tidak lengket tetapi plastis. Dalam keadaan kering tanah ini rapuh dan mengalami penyusutan yang tidak banyak. Hal ini dikarenakan tanah memiliki kandungan pasir yang banyak sehingga susut kering tidak terlalu besar dan terasa lebih ringan. Tanah mudah dibentuk tetapi juga mudah juga terjadi retak-retak terutama saat dibentuk cincin. Tanah dapat digunakan untuk teknik reproduksi tetapi hasilnya masih terjadi retak.

Contoh hasil penelitian secara ilmu keramik yaitu komposisi tanah yang dapat diterapkan untuk teknik reproduksi keramik di sentra gerabah Pagerjurang Bayat Klaten

\begin{tabular}{|c|c|c|c|}
\hline No & Kondisi Tanah & Ukuran $(\mathrm{cm})$ dan berat (gram) & Warna Tanah \\
\hline 1 & Basah & $\begin{array}{l}\text { Panjang basah } 10 \mathrm{~cm} \\
\text { Berat basah }=73 \text { gram }\end{array}$ & Coklat orange \\
\hline 2 & Kering & $\begin{array}{l}\text { Panjang kering } 9,4 \\
\text { Berat kering }=54.60 \text { gram }\end{array}$ & Coklat kuning \\
\hline 3 & Bakar/Bisquit & $\begin{array}{l}\text { Panjang bakar } 9,3 \\
\text { Berat bisquit kering } 54,80 \text { gram } \\
\text { Berat bisquit basah } 58,20 \text { gram }\end{array}$ & Merah terang \\
\hline
\end{tabular}

Analisis:

Tanah menjadi plastis dan mengalami penyusutan bodi tanah yang baik pula. Sangat cocok untuk digunakan pada teknik putar. Hasil test pieces tanah tidak pecah dan dapat digunakan untuk teknik cetak reproduksi walau masih terjadi lengket pada cetakan. Komposisi ini sangat enak digunakan untuk teknik putar dan dapat pula digunakan untuk teknik reproduksi.

\begin{tabular}{llll}
\hline $\begin{array}{l}\text { Tabel 3. } \\
\text { kombinasi ballclay 20\% }\end{array}$ & & WANAH \\
kon & & \\
\hline No & Kondisi Tanah & Ukuran $(\mathrm{cm})$ dan berat (gram) & Warna Tanah \\
\hline 1 & Basah & $\begin{array}{l}\text { Panjang basah } 10 \mathrm{~cm} \\
\text { Berat basah } 73,20 \text { gram }\end{array}$ & Coklat \\
\hline 2 & Kering & $\begin{array}{l}\text { Panjang kering } 9,1 \\
\text { Berat kering }=55,60 \text { gram }\end{array}$ & Coklat crem \\
\hline 3 & Bakar/Bisquit & Panjang bakar $9,2 \mathrm{~cm}$ & Crem tua \\
\hline
\end{tabular}


Berat bisquit kering 49,95 gram

Berat bisquit basah 55,60 gram

\section{Analisis:}

Ball Clay merupakan tanah plastis yang sangat membantu untuk meningkatkan keplastisan suatu campuran tanah. Bahan ini juga mampu meningkatkan suhu bakar tanah. Pencampuran tanah dengan ball clay ini bertujuan untuk membuat campuran tanah lebih baik lagi. Tanah yang sudah diuled lebih baik, halus, dan kuat. Tanah mudah dibentuk, akan tetapi terjadi susut kering yang banyak. Belum maksimal tetapi tanah dapat digunakan untuk teknik reproduksi keramik.

\begin{tabular}{|c|c|c|c|}
\hline No & Kondisi Tanah & Ukuran $(\mathrm{cm})$ dan berat (gram) & Warna Tanah \\
\hline 1 & Basah & $\begin{array}{l}\text { Panjang basah } 10 \mathrm{~cm} \\
\text { Berat basah }=73,20\end{array}$ & Coklat \\
\hline 2 & Kering & $\begin{array}{l}\text { Panjang kering 9,4 } \\
\text { Berat kering }=58,20 \text { gram }\end{array}$ & Coklat tua \\
\hline 3 & Bakar/Bisquit & $\begin{array}{l}\text { Panjang bakar } 9,2 \text { gram } \\
\text { Berat bisquit kering } 56,40 \text { gram } \\
\text { Berat bisquit basah } 58,60 \text { gram }\end{array}$ & Merah tua \\
\hline
\end{tabular}

\section{Analisis:}

Tanah menjadi plastis, sedikit berpasir, dan mengalami penyusutan bodi tanah yang baik pula. Tanah ini dapat digunakan pada teknik putar. Hasil test pieces tanah tidak pecah dan dapat digunakan untuk teknik cetak reproduksi.

Contoh Hasil Test Laboratorium

\begin{tabular}{lllll}
\hline Keterangan \% dan ppm & $\begin{array}{l}\text { Tanah } \\
\text { Godean }\end{array}$ & $\begin{array}{l}\text { Tanah } \\
\text { Temugiring } \\
\text { Pagerjurang }\end{array}$ & $\begin{array}{l}\text { Tanah } \\
\text { Pathuk }\end{array}$ & $\begin{array}{l}\text { Tanah } \\
\text { Dlingo }\end{array}$ \\
\hline Teksture pasir \% & 28.69 & 29.34 & 4.99 & 8.29 \\
\hline Teksture debu \% & 37.2 & 32.06 & 21.23 & 22.15 \\
\hline Lempung aktuil & 38.02 & 39.6 & 15.27 & 26.25 \\
\hline Bahan Organik & 0.865 & 0.617 & 1.192 & 0.577 \\
\hline Si ppm & 40.47 & 135.94 & 167.52 & 195.36 \\
\hline Fe ppm & 24.2 & 20.07 & 9.37 & 4.95 \\
\hline Al ppm & 0.041 & 0.044 & 2.006 & 0.031 \\
\hline Mn ppm & 3.86 & 3.31 & 1.18 & 3.35 \\
\hline Ca ppm & 2635 & 2885 & 1424 & 1140 \\
\hline Mg ppm & 637.1 & 1506 & 490 & 457.6 \\
\hline
\end{tabular}

Proses selanjutnya adalah menguji tanah liat dengan membuat produk dengan teknik-teknik pembentukan yang biasa dilakukan dalam proses produksi gerabah. Teknik-teknik itu adalah teknik putar dan teknik reproduksi dengan cetak. Bahan baku tanah liat yang digunakan juga sama dengan tanah yang digunakan untuk pengujian test pieces. Pengujian dengan membuat produk gerabah dengan teknikteknik di atas akan menguatkan percobaan test pieces yang telah dilakukan. 
Pembuatan produk dengan teknik putar akan dapat mengetahui seberapa tingkat keplatisan tanah. Membentuk produk dengan teknik putar juga akan dirasakan oleh tangan kita seberapa tingkat keenakan tanah atau tingkat kekasaran tanah yang mempengaruhi keuletan tanah. Selain itu juga dilakukan pengujian tanah pada produk dengan teknik reproduksi cetak. Dalam hal ini teknik reproduksi cetak dengan menggunakan bahan gypsum. Pembuatan produk dengan teknik putar dikhususkan untuk produk-produk gerabah yang silindris, sedangkan teknik cetak dikhususkan untuk membuat produkproduk gerabah inovatif non silindris. Sesuai output penelitian, tanah yang dikomposisikan harus dapat diterapkan untuk teknik produksi gerabah dengan teknik putar dan teknik reproduksi yaitu cetak dengan bahan gypsum.

\section{Aplikasi Hasil Tanah Penelitian Dengan Teknik Reproduksi (cetak tekan dan cetak tuang/slip casting)}

Produk gerabah non silindris merupakan produk yang hanya dapat dicapai dengan menggunakan teknik reproduksi cetak. Maka dari itu produk gerabah non silindris proses kerjanya sangat berbeda dengan teknik putar. Teknik reproduksi sangat membutuhkan ketelitian dan kesabaran terutama dalam pembuatan cetakan dengan bahan gypsum. Pembuatan cetakan diawali dengan membuat desain-desain yang menuntut kreatifitas, memiliki pengetahuan tentang produk gerabah yang marketable, dan tetap memiliki nilai fungsional praktis sebagai produk hiasan interior maupun eksterior. Bahkan juga dapat digunakan sebagai produk pakai seperti gelas, vase bunga, piring, dan lainlain.

Keunggulan proses teknik reproduksi keramik adalah memperoleh standar ukuran yang sama, bentuk yang sama, dan ketebalan dinding produk yang merata. Sehingga produk gerabah yang dihasilkan dari teknik reproduksi sangat rapi dan tepat ukuran. Bahkan dari tingkat ketebalan tanah pada produk gerabah yang dihasilkan lebih ringan dan memiliki kepadatan dinding yang lebih baik. Pembuatan produk non silindris dimulai dengan membuat beberapa desain-desain alternatif pada kertas gambar atau ukuran kuarto A4. Dari hasil pembuatan desaindesain alternatif tersebut dipilih dan dijadikan desain jadi yang akan dibuat bentuk/model dengan menggunakan tanah. Model yang dibuat dengan tanah dibentuk sesuai desain dan padat. Pembuatan model dengan massa padat memiliki tujuan agar pada saat model dicetak dengan gypsum akan kuat dan tidak terjadi perubahan bentuk.

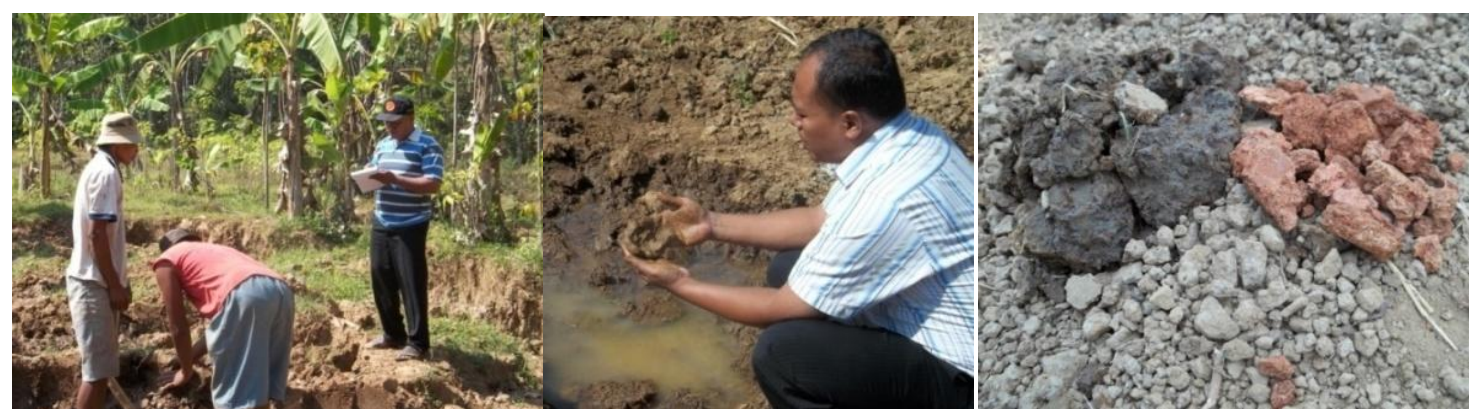

Gambar 1. Proses pendataan bahan baku tanah, identifikasi tanah secara ilmu keramik, dan hasil identifikasi tanah disekitar gunung Temugiring, Merak, dan Cakaran 


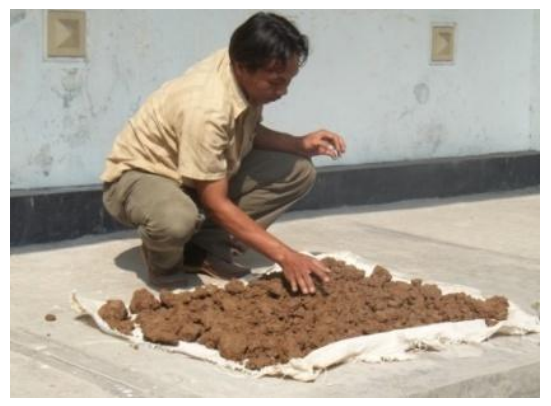

Gambar 2. Proses pengujian tanah yang ada di lapangan dan penjemuran tanah sebelum dilakukan pengujian lebih lanjut.
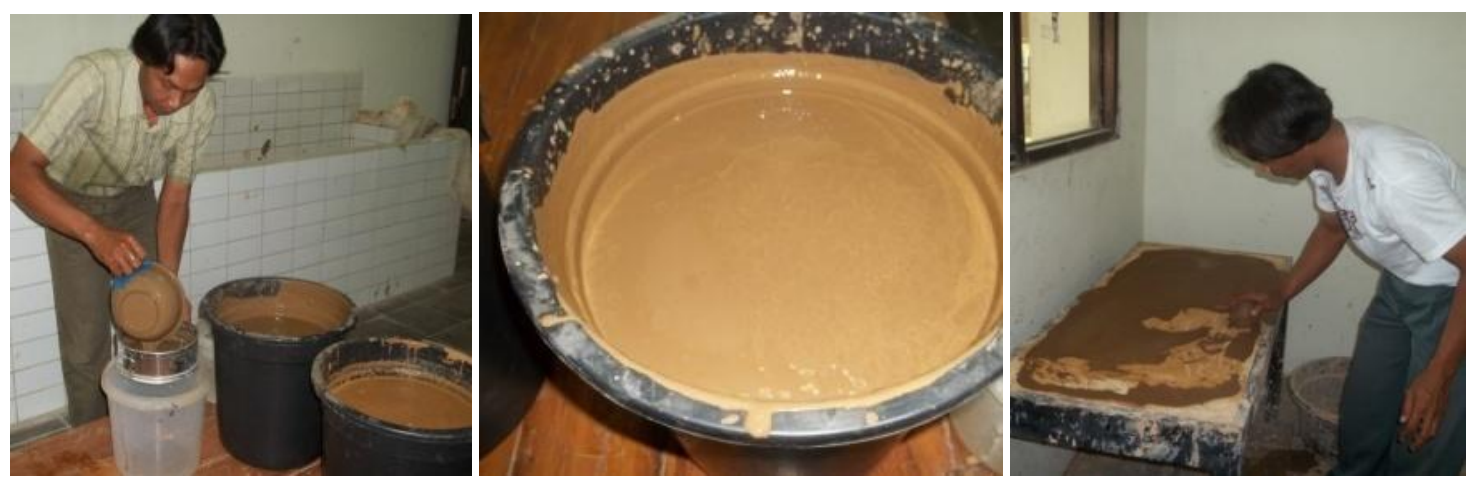

Gambar 3. Proses penyaringan dan pengolahan tanah berdasarkan jenisnya
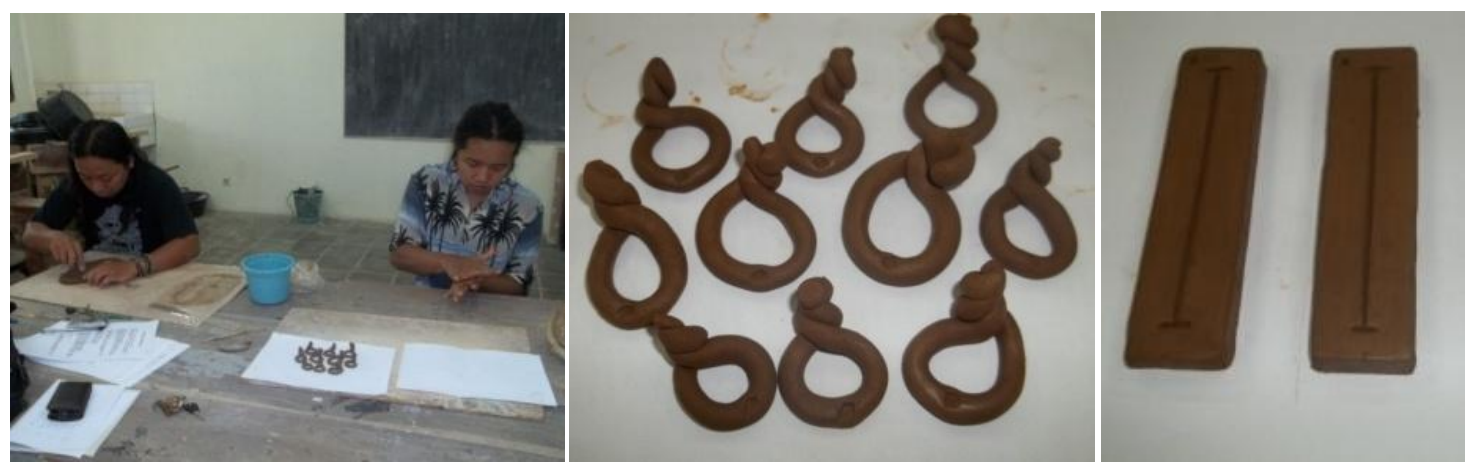

Gambar 4. Proses pengujian tanah secara ilmu keramik (plastisitas tanah) dan pembuatan test pieces terukur
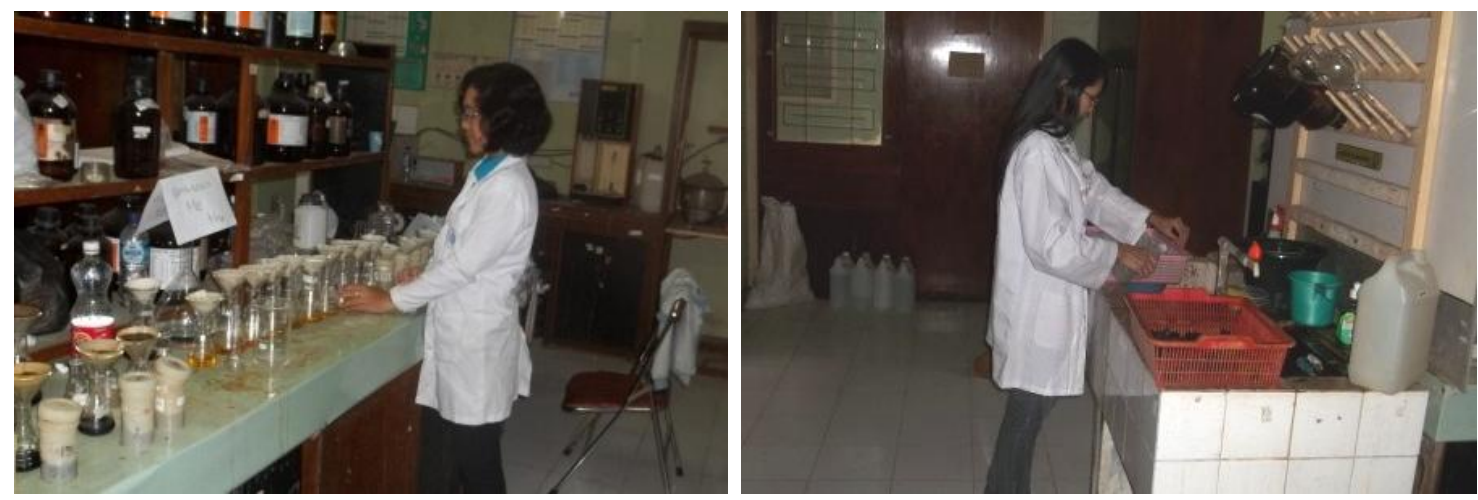

Gambar 5. Proses pengujian tanah secara ilmu kimia di Fakultas Pertanian UGM Yogyakarta 

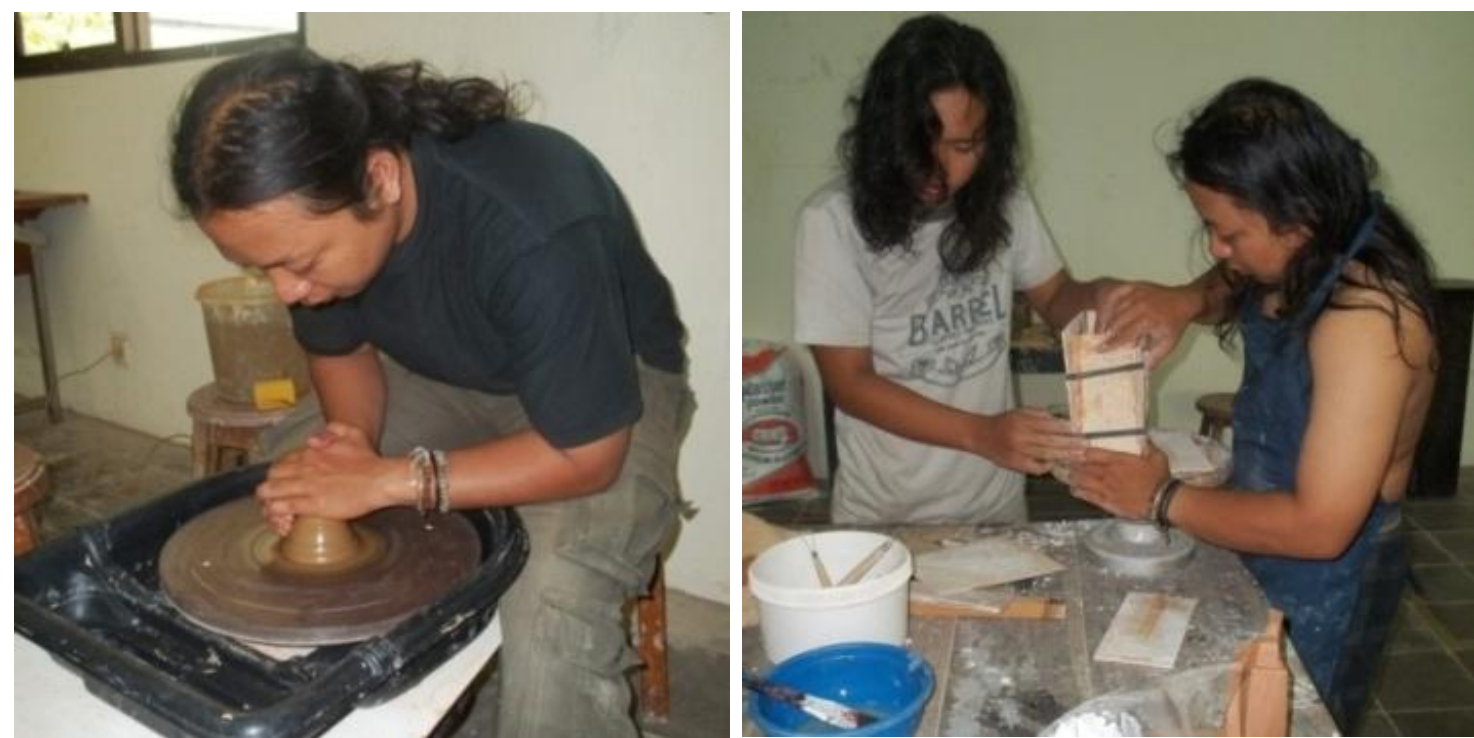

Gambar 6. Proses pengujian tanah dengan teknik putar dan pembuatan model cetak di Studio Keramik ISI Yogyakarta
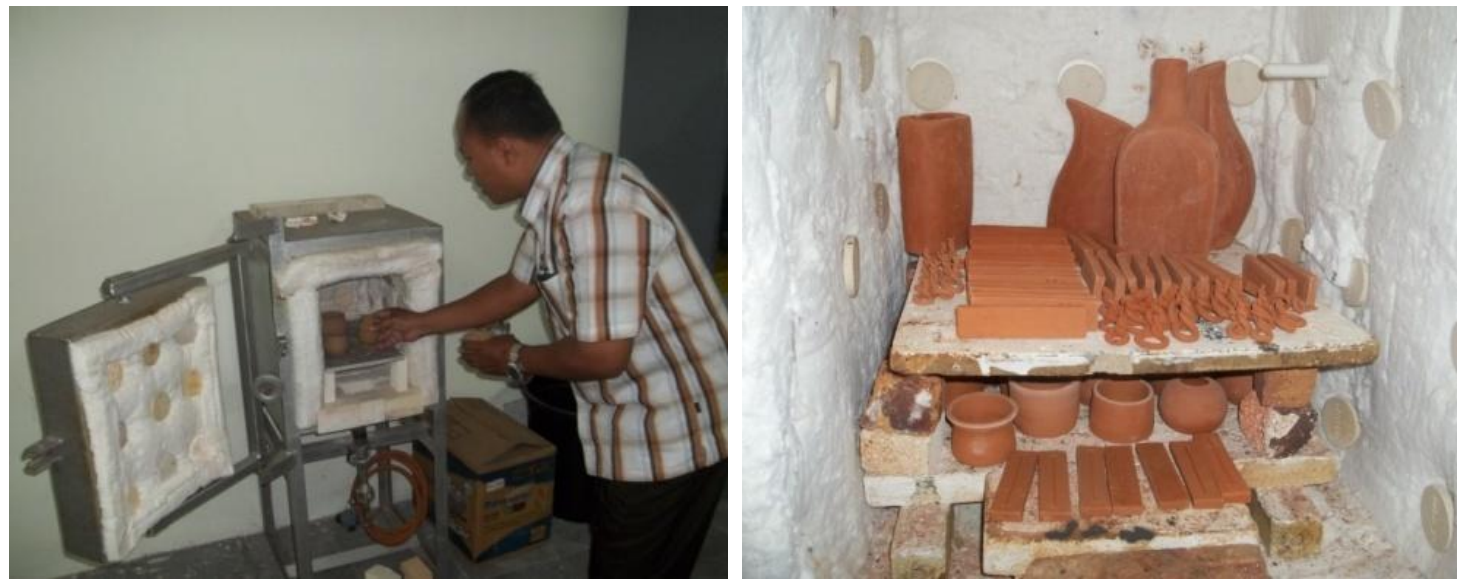

Gambar 7. Proses penataan produk dalam tungku dan hasil bakar produk dengan tungku

\section{KESIMPULAN}

Sentra gerabah Pagerjurang Klaten menghasilkan produk-produk gerabah silindris dengan hasil finishing ngireng yang memiliki ciri khas. Selain itu juga terdapat teknik putar tradisional yang unik yaitu dengan teknik putar miring. Dalam dunia keramik teknik ini disebut teknik putar kickwheel karena menggunakan kaki untuk dapat menggerakkan alat putar. Yang menjadi perbedaan dan menjadi kekuatan gerabah silindris di Pagerjurang yaitu permukaan alat putar atau meja putarnya dalam keadaan miring. Kekayaan teknik putar miring ini patut dilestarikan sebagai aset seni tradisional bangsa kita.

Perkembangan dunia keramik modern menuntut bentuk diversifikasi produk dimana kebutuhan akan desaindesain produk gerabah tidak hanya berbentuk silindris. Konsumen menginginkan ada sentuhan produk yang kreatif dan inovatif selain bentuk-bentuk gerabah silindris. Bentuk-bentuk tersebut dapat ditempuh dengan membuat produk gerabah non silindris. Untuk dapat mencapai bentuk non silindris hanya dapat 
dilakukan dengan teknik cetak atau sering disebut teknik reproduksi keramik.

Seiring dengan pencapaian bentukbentuk non silindris kreatif dan inovatif di sentra gerabah Pagerjurang sangat dibutuhkan keahlian teknik dan bahan tanah yang digunakan. Maka hasil dari penelitian ini merupakan jawaban dan langkah awal dimana telah berhasil melakukan percobaan-percobaan ilmiah dimana telah ditemukan teknik cetak reproduksi gerabah yang tepat dengan komposisi tanah yang ideal. Kandungan tanah liat secara kimiawi sebagai bahan utama untuk membuat produk gerabah di sentra Pagerjurang baik itu untuk teknik putar maupun cetak produk non silindris sudah dapat diketahui. Hal ini akan lebih memudahkan untuk mengadakan pengembangan-pengembangan lebih lanjut terkait dengan bahan utama tanah liat yang digunakan.

Penelitian tahap I telah dilakukan sesuai target penelitian, dimana telah dapat mengidentifikasi bahan tanah liat di sentra Pagerjurang secara ilmu keramik maupun kandungan kimia dalam tanah. Teknik reproduksi keramik dengan bentukbentuk gerabah non silindris dapat dilakukan dengan cetak dari bahan gypsum dengan komposisi tanah yang baik pula. Telah tercipta 20 desain produk gerabah non silindris sebagai prototipe dengan master cetakan produk dari bahan gypsum. Prototype tersebut dapat menjadi master desain dan dapat digunakan sebagai cetakan untuk dapat digandakan oleh pengrajin gerabah di sentra gerabah Pagerjurang Bayat Klaten Jawa Tengah.

\section{DAFTAR PUSTAKA}

Astuti, Ambar, 2001, Pengetahuan Keramik, Yogyakarta: Gadjah Mada University Press
, 2008, Keramik: IImu dan

Proses Pembuatannya, Jurusan

Kriya, Fakultas Seni Rupa, Institut Seni Indonesia Yogyakarta

Alexander, Brian, 2001, Kamus Keramik, Jakarta, Penerbit Milenia Populer

Chavarria, Joaquim, 1994, The Big Book of Ceramics, New York, WatsonGuptil Publications

Clark, Kenneth, 1986, The Potter's Manual, New Jersey: Chartwell Books. Inc

Colbeck, John, 1987, The Technique of Pottery, London, BT Bestford Limited

Daryono, Natas Setiabudi, 2001, Pengenalan Keramik, Bandung, Indy Label

Fischer, Joseph, 1994, The Folk Art of Java, Oxford University Press, Oxford, Singapore, New York, Kualalumpur

Gustami, Saptoto, Narno S, 1985, Pola Hidup dan Produk Kerajinan Keramik Kasongan Yogyakarta, Departemen Pendidikan dan Kebudayaan Direktorat Jendral Kebudayaan Proyek Penelitian dan Pengkajian Kebudayaan Nusantara

Hogan, Elizabeth, 1977, Ceramic Techniques and Project, California Penerbit Lane Publishing CO, Menlo Park

Isa Darmawijaya, M., 1997, Klasifikasi Tanah, Yogyakarta, Gadjah Mada University Press

Moleong, Lexy J, 2004, Metodologi Penelitian Kualitatif, Penerbit PT Remaja Rosdakarya, Bandung 
Muhammad Suin, Nurdin, 2003, Ekologi Hewan Tanah, Jakarta, Penerbit Bumi Angkasa

Mucthar, But, 1991, "Daya Cipta Bidang Kriya" dalam SENI, Jurnal Pengetahuan dan Penciptaan Seni, VII/01, BP ISI Yogyakarta

Raharjo, Timbul, 2008, Seni Kerajinan Keramik Kasongan Yogyakarta Di Era Globalisasi: Perjalanan Dari Dusun Gerabah Menjadi Sentra Seni Kerajinan Keramik Yang Mendunia, (Disertasi), Universitas Gadjah Mada, Yogyakarta

R.A. Razak, 1981, Industri Keramik, Jakarta, Balai Pustaka
Soedarsono, R.M, 1999, Metodologi

Penelitian Seni Rupa dan

Pertunjukan, Masyarakat Seni

Pertunjukan Seni Indonesia,

Bandung

Soekiman, Djoko, 2000, Kebudayaan Indis Dan Gaya Hidup Masyarakat Pendukungnya Di Jawa, Yayasan Bentang Budaya, Yogyakarta

Sumartono, 2003, Berbagai metode/pendekatan dalam penelitian Desain, Institut Seni Indonesia Yogyakarta, Yogyakarta

Yumarta, Yardini, 1981, Keramik, Bandung, Penerbit Angkasa 